\title{
The Effect of Product Quality on Customer Loyalty with the Mediation of Customer Satisfaction
}

\author{
Rina Rahmawati ${ }^{*}$, I P. Eka Sentana ${ }^{2}$ \\ ${ }^{I}$ STIE Malangkucecwara Malang, East Java, Indonesia \\ ${ }^{2}$ Postgraduate Student at STIE Malangkucecwara Malang, East Java, Indonesia
}

*Corresponding Authors: Rina Rahmawati, STIE Malangkucecwara Malang, East Java, Indonesia. email: riinarinaa@stie-mce.ac.id

\begin{abstract}
The aim of this study is to determine the effect of frozen semen quality on customer loyalty with the mediation of customer satisfaction of Singosari National Artificial Insemination Center (SNAIC) Malang, Indonesia. This research investigates the effect of frozen semen quality on customer satisfaction, effect of customer satisfaction on customer loyalty, direct effect of product quality on customer loyalty and the role of customer satisfaction in mediating the effect of product quality on customer loyalty. The population is the active inseminator technicians from 3 provinces i.e. East Java, Central Java and Special Region of Yogyakarta. Total sample of 338 respondents is drawn using proportionate stratified random sampling. The model analysis is Structural Equation Model-Partial Least Square (SEM-PLS). The result showed that product quality has positive and significant effect on customer satisfaction. Customer satisfaction also has positive and significant effect on customer loyalty. Product quality has positive and significant effect on customer loyalty, either directly or through the mediation of customer satisfaction. It is concluded that customer satisfaction gives strong effect on the customer loyalty of SNAIC frozen semen.
\end{abstract}

Keywords: artificial insemination, frozen semen, product quality, customer satisfaction, customer loyalty

\section{INTRODUCTION}

Artificial Insemination (AI) is the single most important reproductive biotechnology to improve livestock genetic and productivity. This technique is widely used for dissemination of superior genetic material of outstanding male (Singh and Balhara, 2016). Therefore, AI technology should be supported by high quality frozen semen. Frozen semen is livestock seed that is used to inseminate female livestock to optimize superior bull genetic in order to increase livestock genetic quality and its productivity (Toelihere, 1979).

Along with the popularity of AI program in Indonesia and the knowledge improvement of livestock farmers in rural area, the demand for frozen semen is increasing. The demand for frozen semen in Indonesia is supplied by national and regional AI Centers. Singosari National AI Center (SNAIC) Malang in East Java Province is one of the largest frozen semen producers in Indonesia.

The tight competition in frozen semen market in Indonesia requires SNAIC to develop their marketing strategy. Marketing strategy with quality oriented is necessary to achieve customer satisfaction. The purpose of marketing strategy is to strengthen the competitive position to attract new customers and maintain their loyalty (Almsalam, 2014). A company that is able to compete and survive is a company that can provide quality products and maintain its quality to preserve customer satisfaction (Iriyanti, Qomariah, \& Suharto, 2016).

According to Kotler \& Keller (2018:72), customer's feedback is important part of marketing strategy that should be monitored. Customer's feedback should be responded to prevent the decrease of selling rate or even losing customers due to the poor customer service. Company should provide product with the best quality to meet customer expectation. Based on the description above, study to analyze frozen semen selling at SNAIC is need to carried out to analyze the effect of frozen semen quality on customer satisfaction at the level of AI technicians as frozen semen consumers.

\section{LITERATURE REVIEW}

\subsection{Product Quality}

There is a close relationship between product quality with customer satisfaction and company profitability where the product with high quality is positively correlated with customer satisfaction 
(Abdullah \& Tantri, 2019: 43). Arianty (2015) also reports that product quality is related to its ability to satisfy consumers, which is sometimes accompanied by customer's feedback for future improvement.

Product quality is a major point for the company's existence (Priansa, 2017: 51). Quality can influence consumers to establish strong relationships with companies by defining consumer expectations carefully. According to Tjiptono\& Diana (2019: 93), there are 8 factors that is commonly used by consumers to evaluate their satisfaction or dissatisfaction on particular products, namely (1) performance, (2) features, (3) reliability, (4) conformance to specifications, (5) durability, (6) serviceability, (7) aesthetic, and (8) perceived quality.

\subsection{Customer Satisfaction}

According to Kotler \& Keller (2018: 179) companies should systematically measure customer satisfaction and analyze its factors in order to retain customers. A very satisfied customer fosters loyalty. Companies need to maintain good communication and relationships to preserve customer loyalty. Customer satisfaction can be identified through consumer satisfaction survey which includes complaints and feedback, shadow buyers, and analysis of switching consumers. According to Tjiptono\& Diana (2019: 130) there are 4 parameters that could be used to measure customer satisfaction, namely (1) satisfaction towards quality, (2) satisfaction towards value, (3) perceived best, and (4) customer expectations.

\subsection{Customer Loyalty}

According to Priansa (2017: 219) there are 2 main perspective of consumer loyalty in defining and measuring loyalty as behavior and loyalty as attitude, namely (1) behavioral loyalty and (2) attitudinal loyalty. Behavioral loyalty is measured through the purchasing behavior. The measured dimensions are consumers who still actively making purchases and who keep making purchases. Attitudinal loyalty is measured through the consumer attitudes towards the company. In this case, consumers have a high preference and commitment to the company.

Loyalty is a combination of customer satisfaction and customer repurchase behavior. Customers who satisfied with particular products/services may enhance their attitudes to support the producer company. These attitudes include give positive comment about products, recommending the company to others, being loyal to the company's products or paying for products at a premium price (Lupiyoadi, 2018:257).

Based on the purpose of research and literature reviews, it can be prepared the conceptual framework of the study as presented in Fig 1.

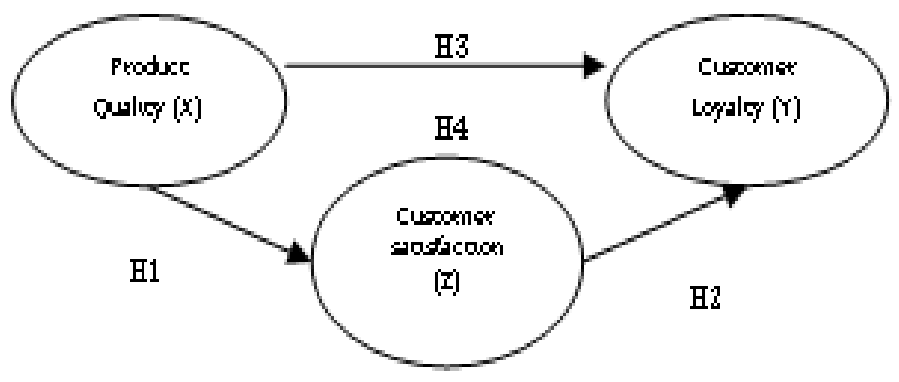

Fig1. Conceptual Framework

Referring to the conceptual framework, this study will test four hypotheses as follows:

H1 : Hypotheses 1

$\mathrm{H} 2$ : Hypotheses 2

H3 : Hypotheses 3

H4 : Hypotheses 4

A product is defined as anything that can be offered to the market for attention, acquisition, use or consumption that could satisfy a need or want (Abdullah \& Tantri, 2019:153). Customers also tend to assume that products as a set of benefits that satisfy their needs. To obtain customer satisfaction, product quality must meet or exceed customer expectations. 
To understand consumer expectations is very important in marketing strategy. If the service quality is higher than expectations, consumers will deem the provided services are satisfying and pleasant. Customer expectations enhance along with the improvement of customer experience (Musanto, 2014).

Product quality is a key factor for company survival. Companies that slow to respond customer needs will result in customer unsatisfied and leads to decrease their profits (Ishaq et al., 2014). Hayati\&Sekartaji (2015) investigate the effect of product quality on consumer satisfaction in culinary industry. The result showed a significant effect of product quality on consumer satisfaction. Arianty (2015) also investigates the effect of service and product quality on consumer satisfaction in telecommunication industry and shows that there is an effect of product quality on consumer satisfaction. Several studies have been conducted which explain the role of product quality on customer satisfaction which leads to influence customer loyalty (Kusumah, 2018; Jahanshahi et al., 2011; Paramitha-Wendha et al., 2013). High product quality will lead to increase customer satisfaction. Therefore, the following hypothesis can be formulated:

\section{H1: Product quality affects customer satisfaction}

The main purpose of corporate services is to achieve customer satisfaction. If high customer satisfaction is achieved, it leads to increase customer loyalty (Lupiyoadi, 2018: 246). According to Abdullah \& Tantri (2019: 45), customer satisfaction is a positive feeling obtained by customers because the company's performance is able to meet their expectations. The satisfied customers could be achieved if their expectations are met or exceeded. Furthermore, Tjiptono\& Diana (2019) explained that satisfaction is the consumer's response to evaluate the perception between initial expectations and actual performance.

According to Paramitha-Wendha et al. (2013) reported that service quality has a positive and significant effect on customer satisfaction of Garuda Indonesia Airlines. It shows that service quality has linear effect on customer satisfaction. The same study also shows that customer satisfaction has a positive and significant effect on customer loyalty, as well as service quality has a positive and significant effect directly on customer loyalty. Sa'adah et al., (2019) reported that $74.57 \%$ of livestock farmer as the customers of artificial insemination service are categorized as satisfied. Therefore, the quality of artificial insemination services are exceeds farmer's expectations.

According to Hermawan (2011), consumer satisfaction does not directly affect consumer's loyalty in herbal product industry due to the product is classified as a convenience good. Therefore, consumers can easily switch to similar products from other brands. The studies which investigate the effect of service and product quality on customer satisfaction and loyalty in restaurants industry was conducted by Putro et al. (2014) and Sembiring et al. (2014) shows that consumer satisfaction has positive and significant effect on customer loyalty. Another study conducted by Srivastava \& Rai (2013) reported that customer satisfaction has a significant and positive effect on customer loyalty in the insurance industry in India. In this case, the factors that influence customer satisfaction should be considered as the major concern in the insurance industry, such as staff skills, company transparency and competitive prices to increase customer loyalty. The satisfied customers tend to be loyal customer. Therefore, the following hypothesis can be formulated:

\section{H2: Customer satisfaction affects customer loyalty}

Quality is a product appearance or service performance which is a major part of company's strategy in order to achieve competitive advantage, either as a market leader or as a market innovator (Priansa, 2017: 51). Experience on a particular product will give impression on customer's mind or feeling of satisfaction and dissatisfaction which affects subsequent behavior. The satisfied customer will show repurchase behavior and recommend the product to others (Lupiyoadi, 2018: 249). The satisfied and dissatisfied is influenced by product quality.

A study to determine the relationship between customer service and product quality with customer satisfaction and loyalty in automotive industry in India shows a high positive correlation between customer service and product quality with customer satisfaction and loyalty (Jahanshahi et al., 2011). Other research also states that there is a positive relationship between product and service quality on customer loyalty in the retail market in Kosovo (Xhema et al., 2018). A more detailed research was conducted by Yuen and Chan (2010) on the retail market in Hong Kong and it is known that there are 4 quality dimensions that have positive effect on customer loyalty. Three dimensions affect customer 
loyalty to the company (i.e. physical aspects, toughness, and problem solving) and 1 other dimension (personal interaction) affects customer loyalty to the company staff. There is a tendency that customers who are satisfied with the quality of a product will tend to have high loyalty, so the hypothesis is as follows:

\section{H3: Product quality affects customer loyalty}

Customer loyalty should be maintained as a major priority by company. Customer loyalty is a psychological commitment on a particular brand.Loyal consumers offer a sustainable revenue for a company by remaining with the brand or supplier and rejecting competitor offerings (Tjiptono\& Diana, 2019:297).Priansa (2017:217) identified loyalty as a long-term commitment and willingness of customers to repurchase the service or product, and to maintain a relationship with the service provider or supplier. Therefore, to retain the organization's current customers and to make them loyal is a critical component for a company to be successful. According to Kotler \& Kotler (2018:193-195) company should invest to create loyal customer due to it contributes to increase companies profitability. Loyal customers offer a steady stream of revenue for a company by remaining with the brand or supplier, positive word-of-mouth, willing to pay higher prices and are less price sensitive (Abdullah \& Tantri, 2019:45).

A study in the retail companies in Pakistan shows that customer satisfaction is a partial mediating variable which connects between product quality, company image and perceive value on customer loyalty (Ishaq et al., 2014). Other study in the hotel industry also indicates that there is a positive relationship between service quality and customer loyalty through the satisfaction as an intervening variable (Priyo et al., 2019). Hartono \&Raharjo (2015) separated cognitive satisfaction and effective satisfaction as an intervention to customer loyalty in the hotel industry in Surabaya City, Indonesia. It is known that the two satisfaction variables have a significant role as intervening variable which connect between service quality and customer loyalty. Andreas (2016) examined the effect of product quality on customer loyalty with satisfaction as an intervening variable in the restaurant industry. $\mathrm{He}$ reported that product quality had a significant and positive effect on customer satisfaction and customer loyalty. Customer satisfaction has a significant and positive effect on customer loyalty. The indirect effect of product quality on customer loyalty through the mediation of customer satisfaction has a higher coefficient value than the direct effect. This means that customer satisfaction plays an important role as a mediation variable in order to create customer loyalty. Therefore, the following hypotheses can be formulated:

\section{H4: Product quality affects customer loyalty through the mediation of customer satisfaction}

\section{Methodology}

\subsection{Data Collection}

Data collection was carried out using questionnaire which was measured with five-points Likert scale, namely (5) strongly agree, (4) agree, (3) neutral, (2) disagree, and (1) strongly disagree. The population of this study consists of all active inseminator technicians in 3 provinces (East Java, Central Java, and Special Region of Yogyakarta) as a secondary customer who have used SNAIC frozen semen for more than 2 years. Total population of 2,194 technicians consists of 1,513 technicians from East Java Province, 570 technicians from Central Java Province and 111 technicians from Special Region of Yogyakarta. Total sample of 338 respondents is drawn using proportionate stratified random sampling (Sugiyono, 2012:134).

\subsection{Validity and Reliability Analysis}

Reliability is the consistency and stability of measurement or the degree to which an instrument measures the same way each time it is used under the same condition with the same subjects. For determining reliability of the study Cronbach's Alpha method was used (>0.6). Validity refers to which a measure adequately represents the underlying construct that it is supposed to measure. A valid instrument should has higher corrected Item Total Correlation than r-table (0.106). Validity and reliability analysis was carried out using SPSS 16 for Windows.

\subsection{Descriptive Analysis}

Descriptive statistic was used to describe the basic features of the data in this study to calculate index value with the following formula: 
$(\%$ strongly disagree $\times 1)+(\%$ disagree $\times 2)+$

Index Value $=\frac{(\% \text { neutral } \times 3)+(\% \text { agree } \times 4)+(\% \text { strongly agree } \times 5)}{5}$

Index value scale:
$01-20 \% \quad$ : very bad
$21-40 \% \quad:$ bad
$41-60 \% \quad$ : fair
$61-80 \% \quad: \operatorname{good}$
$81-100 \% \quad$ : very good.

\subsection{SEM-PLS Analysis}

Structural Equation Model-Partial Least Square (SEM-PLS) was used to analyze the data collected for this study. Smart PLS 3.3.2 was used to assess the measurement model and the structural model of the proposed model in this study. The aim of SEM-PLS analysis is to determine the effect of $\mathrm{X}$ variable on $\mathrm{Y}$ variable and describe the relationship of both variables.

\section{RESULTS AND DISCUSSION}

\subsection{Characteristic of Respondents}

Table1. Characteristic of Respondents

\begin{tabular}{|c|c|c|c|}
\hline Parameter & Description & $\mathbf{N}$ & $\%$ \\
\hline \multirow{2}{*}{ Sex } & Male & 328 & $97,04 \%$ \\
\hline & Female & 10 & $2,96 \%$ \\
\hline \multirow{5}{*}{ Age } & $20-30$ & 76 & $22,49 \%$ \\
\hline & $31-40$ & 83 & $24,56 \%$ \\
\hline & $41-50$ & 98 & $28,99 \%$ \\
\hline & $51-60$ & 72 & $21,30 \%$ \\
\hline & $>60$ & 9 & $2,66 \%$ \\
\hline \multirow{5}{*}{ Education } & $\begin{array}{l}\text { Junior High School } \\
\text { Senior High School }\end{array}$ & $\begin{array}{l}6 \\
179\end{array}$ & $\begin{array}{l}1,78 \% \\
52,96 \%\end{array}$ \\
\hline & Diploma & 42 & $12,43 \%$ \\
\hline & Bachelor & 92 & $27,22 \%$ \\
\hline & DVM & 16 & $4,73 \%$ \\
\hline & Post Graduate & 3 & $0,89 \%$ \\
\hline \multirow{2}{*}{ Marital Status } & Not Married & 39 & $11,54 \%$ \\
\hline & Married & 299 & $88,46 \%$ \\
\hline \multirow{6}{*}{ Number of Acceptor per month } & $\leq 100$ & 154 & $45,56 \%$ \\
\hline & $101-200$ & 112 & $33,14 \%$ \\
\hline & $201-300$ & 39 & $11,54 \%$ \\
\hline & $301-400$ & 14 & $4,14 \%$ \\
\hline & $401-500$ & 10 & $2,96 \%$ \\
\hline & $>500$ & 9 & $2,66 \%$ \\
\hline \multirow{4}{*}{ Utilization of SNAIC Frozen Semen (doses per month) } & $\leq 100$ & 186 & $55,03 \%$ \\
\hline & $101-200$ & 108 & $31,95 \%$ \\
\hline & $201-300$ & 31 & $9,17 \%$ \\
\hline & $>300$ & 13 & $3,85 \%$ \\
\hline \multirow{2}{*}{ Use frozen semen beside SNAIC product } & Yes & 267 & $78,99 \%$ \\
\hline & No & 71 & $21,01 \%$ \\
\hline
\end{tabular}

The majority of AI technicians (45.56\%) have less than 100 cow acceptors in each service area. The average utilization of SNAIC frozen semen per month also less than 100 doses for each AI technician (55.03\%). The number of cow acceptor not always in line with the number of frozen semen usage per month due to 3 reasons. First, not all acceptor receive AI service due to limited availability of frozen semen in the field. Second, an AI technician cannot cover the large number of acceptors due to the wide scope of service area and limited transport facilities. Third, the acceptors may be inseminated with frozen semen from other producer. According to Table 1 the majority of SNAIC consumers also 
use frozen semen from other producers $(78.99 \%)$. The technician's age related with their ability to adopt new knowledge and technology. In this regards, age is divided into 4 categories namely early adopter (25-40 y.o); early majority (41-45 y.o); late majority (46-50 y.o); laggard (>50 y.o) (Nurlina, 2007). If compared with those classification, only $23.96 \%$ of respondent are categorized as laggard. Therefore, the majority of respondent could adopt new innovation and technology regarding livestock improvement.

\subsection{Descriptive Analysis}

The responses from respondents on product quality indicated that consumer perceptions on the quality of SNAIC frozen semen obtained an average index value of $89.41 \%$. It is categorized as very good $(81-100 \%)$. The indicator of "different color for each cattle breed" has highest index value $(93.31 \%)$. It shows that color coding for each cattle breed conforms to national regulation. It is important to avoid mistakes in the breed selection of frozen semen during AI service. On the other hand, the indicator of "SNI (Indonesian National Standard) certified of frozen semen" also obtained similar index value (93.31\%) which indicated that SNAIC frozen semen has been trusted by consumers and proven in the field. Indicator with the lowest index value $(82.01 \%)$ is "SNAIC frozen semen has comparative advantage over frozen semen from other producers".

The responses from respondents on customer satisfaction obtained an average index value of $82.83 \%$ which is categorized as very good (81-100\%). Indicator of "Overall SNAIC services is very good" obtained highest score of index value (89.23\%). It indicates that SNAIC in general gives good quality of services to the customers. Indicator with the lowest score of index value $(68.28 \%)$ is "repeat breeding are rarely happened". Although it is categorized as "good", however this problem is a major challenge that is faced by livestock farmers in Indonesia. There are several factors that affect the successful of AI program. The quality of frozen semen is one of the factor. The other factors such as timing for AI, frozen semen handling by field technicians, and fertility of the cow also influence the successful of AI program (Toelihere, 1979).

The responses from respondents on customer loyalty obtained an average index value of $82.24 \%$ which is categorized as very good $(81-100 \%)$. Indicator with the highest score of index value $(86.80 \%)$ is "Customer trust the quality of SNAIC frozen semen with international standard". It shows that SNAIC frozen semen has comparative and competitive advantage in the market. Therefore, this indicator should be maintained to sustain the brand image of SNAIC frozen semen especially for word-of-mouth promotion in the level of field technicians and livestock farmers. According to Almsalam (2014), customer expectation is formed from their experience, expert opinion, advertisement, media publication and word-to-mouth promotion. Indicator with the lowest score of index value (79.11\%) is "Remain loyal on SNAIC frozen semen even though there are shortcomings".

\subsection{SEM-PLS Analysis}

Structural Equation Model (SEM) analysis with Partial Least Square (PLS) approachment is used to identify the relationship among latent variables and also the relationship between latent variable and its indicators. The 2 models of SEM-PLS analysis namely outer model and inner model were analyzed. Outer model (measurement model) describe the relationship between each indicator and its construct. The evaluation of outer model consists of convergent validity (obtained from loading factor, average variance extracted (AVE), and composite reliability) and discriminant validity which is obtained from cross loading value. Inner model describes the relationship among each construct which is evaluated by the value of $\mathrm{R}^{2}$ and path coefficient.

\section{Outer Model Analysis}

Outer model analysis is used to describe the relationship between indicator and its construct / latent variable. Convergent validity is obtained from loading factor $(>0.7)$, AVE (>0.5), composite reliability $(>0.7)$ and Cronbach's Alpha ( $>0.6)$ (Hair et al., 2009). Initial model of product quality has 24 indicators, customer satisfaction has 13 indicators and customer loyalty has 9 indicators. After testing, it was found that there were several indicators that had loading factor value $<0.7$, so they had to be eliminated and re-analyzed. The results of the re-analysis obtained a new model that explains the variables of product quality, customer satisfaction and customer loyalty, all of which have met the requirements. Indicator with the high loading factor value, indicates it has a higher contribution to explain the latent variable. 


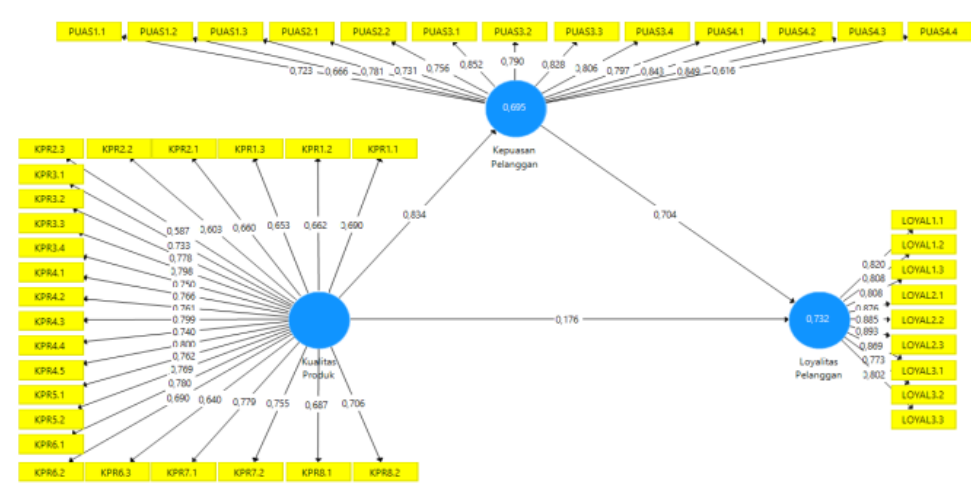

Fig2. Initial model.

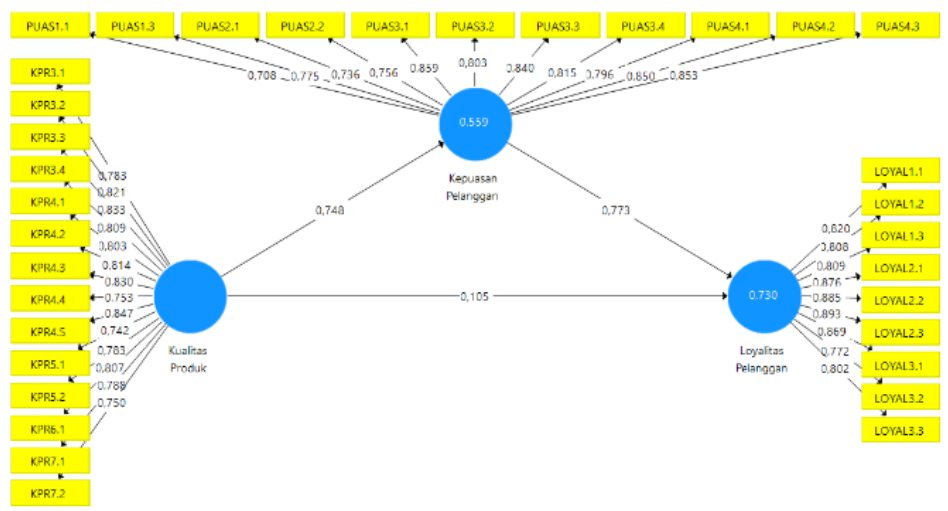

Fig3. Final model.

The construct of product quality could be reflected by 14 indicators. Indicator with the highest loading factor value (0.847) is KPR4.5 "Frozen semen is produce from superior bull with high genetic and disease free". It indicates that genetic superiority is a major concern of consumers due to it will be inherited to the offspring. The purpose of artificial insemination program is to improve livestock genetic through optimizing the role of high genetic sire. With natural mating a bull could serve only 100-200 cows annually. However, with artificial insemination technology, one ejaculate of semen could be produced 180-600 doses of frozen semen (Schuh, 1992). The high genetic potency of bull could be disseminated to improve livestock genetic in the field population and leads to increase their productivity. Therefore, bull as semen source should meet the standard.

Customer satisfaction could be reflected by 11 indicators and indicator with highest value of loading factor (0.859) is PUAS3.1 "the specification of SNAIC frozen semen has met customer expectation". It indicates that customer satisfaction could be achieved if the specification of SNAIC frozen semen in line with customer expectation. The specification of SNAIC frozen semen refers to Indonesian National Standard (SNI 4869-1:2017). It means that every single dose of frozen semen has at least 25 million of spermatozoa per straw and $40 \%$ of post thawing motility. Therefore, conception rate could be optimized.

Customer loyalty could be reflected by 9 indicators. Indicator with the highest value of loading factor (0.893) is LOYAL2.3 "Recommend SNAIC frozen semen to friends or colleagues". It shows that AI technicians as secondary customer of SNAIC frozen semen have willingness to recommend SNAIC frozen semen to livestock farmers and other AI technicians. It indicates that the positive behavior of word-of-mouth promotion has been carried out by AI technicians due to the proven quality of SNAIC frozen semen.

Convergent validity is measured by the value of average variance extracted (AVE). A model with good validity should has AVE higher than 0.5. Table 2 shows that all constructs have AVE higher than 0.5 which indicate that all construct have good validity. According to result of reliability analysis, it shows that the value of composite reliability is higher than 0.70 and Cronbach's Alpha is higher than 0.6 and could be concluded that all constructs have good, accurate and consistent reliability. Discriminant validity is measured by the value of cross loadings with the correlation value higher than 0.7. All indicators have higher loading value for their own construct compared to other construct. 
Table2. Value of AVE, Cronbach's Alpha and Composite Reliability

\begin{tabular}{|l|l|l|l|l|}
\hline No & Construct & AVE & Cronbach's Alpha & Composite Reliability \\
\hline 1 & Product Quality & 0,637 & 0,956 & 0.961 \\
\hline 2 & Customer Satisfaction & 0,641 & 0,944 & 0.951 \\
\hline 3 & Customer Loyalty & 0,702 & 0,947 & 0.955 \\
\hline
\end{tabular}

Inner Model Analysis

Inner model analysis aims to determine the relationship among constructs either exogenous or endogen variable. It is measured by the value of bootstrapping among construct. The overall effect of independent variable on dependent variable could be determined by $\mathrm{R}^{2}$ value. According to Table 3 , the value of $\mathrm{R}^{2}$ on customer satisfaction is $0.559(55.9 \%)$. It indicates that product quality contributes $55.9 \%$ on customer satisfaction. The remaining $44.1 \%$ is explained by the other factors. R2 value on customer loyalty is 0.730 which indicates that product quality contributes $73 \%$ on customer satisfaction. The remaining $27 \%$ could be explained by the other factors.

Table3. R-Square Value

\begin{tabular}{|l|l|l|}
\hline No & Construct & R-Square \\
\hline 1 & Customer satisfaction & 0,559 \\
\hline 2 & Customer loyalty & 0,730 \\
\hline
\end{tabular}

According to the result of bootstrapping also obtained the value of path coefficient which describes the causal effect among constructs and define the significance. The value of T-statistics indicates the significance of model which describes the effect of hypotheses on each path between exogenous and endogen variable. The value of original sample describes the attribute of relation among constructs (positive or negative). Exogenous variable has significant effect on endogen variable if the value of TStatistics is higher than t-table $(\alpha 0.05=1.96)$.

Table4. Path Coefficient

\begin{tabular}{|l|l|l|l|}
\hline Hypotheses & $\begin{array}{l}\text { Original } \\
\text { Sample }\end{array}$ & T-Statistics & $\begin{array}{l}\boldsymbol{P} \text { - } \\
\text { Value }\end{array}$ \\
\hline Product quality $\rightarrow$ Customer satisfaction & 0,748 & 33,145 & 0,000 \\
\hline Customer satisfaction $\rightarrow$ Customer loyalty & 0,773 & 18,672 & 0,000 \\
\hline Product quality $\rightarrow$ Customer loyalty & 0,105 & 2,169 & 0,030 \\
\hline Product quality $\rightarrow$ Customer satisfaction $\rightarrow$ Customer loyalty & 0,578 & 16,242 & 0,000 \\
\hline
\end{tabular}

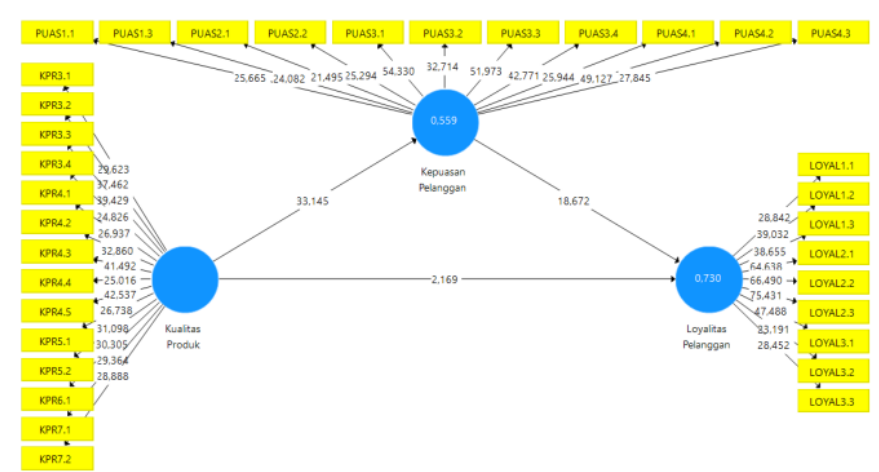

Fig4. Bootstrapping result.

According to Table 4 it shows that all hypotheses have a significant effect. Product quality significantly affects customer satisfaction (H1). It indicates that to achieve customer satisfaction SNAIC should improve its frozen semen quality. Abdullah \& Tantri (2019:43) states that there is a strong relationship between product qualities on customer satisfaction and company's profitability. Product quality has positive and significant effects on customer satisfaction. Therefore, it could increase the rate of sales which leads to increase company's profitability. Other effort to maintain and improve customer satisfaction is to implement marketing relationship strategy. It could be done though monitoring and evaluation to strengthen the positive and sustainable relationship between company and customers (Saputra, 2009). According to Kotler \& Keller (2018:72) feedback and control is necessary on marketing strategy. A company should trace the feedback from customer and respond appropriately. 
Customer satisfaction has positive and significant effect on customer loyalty (H2). It indicates that to achieve customer loyalty, SNAIC product should meet customer expectation to satisfy customers. To maintain customer loyalty, SNAIC should preserve and improve its frozen semen quality to meet customer satisfaction. Beside customer satisfaction, product quality also has significant effect on customer loyalty either directly (H3) or with the mediation of customer satisfaction (H4). The direct effect of product quality on customer loyalty could be said that the dissatisfied customer shows repurchase behavior due to situational factors. It depends on the size of hindrance to move to other brand because of technical, psychological or economic factors (Mardalis, 2005).

Loyal customers are they who satisfy with the product quality of frozen semen. It is accordance with Andreas (2016) who reported that the effect of product quality on customer loyalty with the mediation of customer satisfaction has higher coefficient value than the direct effect of product quality on customer loyalty. It indicates that customer satisfaction plays an important role as intervening variable. According to the result of this study, product quality either directly or with the mediation of customer satisfaction has positive and significant effect on customer loyalty. Therefore it could be said as partial mediation (Budhiasa, 2016).

\section{CONCLUSION}

According to the result of this study could be concluded that product quality has positive and significant effect on customer satisfaction. The indicators that contributes strongest effect are "high genetic quality and free of disease", "strict quality control during production process" and "SNI certified guarantee". It also shows that customer satisfaction has positive and significant effect on customer loyalty. The indicators that have highest loading factor are "frozen semen specification meet customer expectation", "the quality obtained equal with the money spent" and "the customers recognize that SNAIC frozen semen has excellent quality". The result of analysis shows that either direct or with the mediation of customer satisfaction, product quality has significant and positive effect on customer loyalty (partial mediation).

\section{ACKNOWLEDGMENTS}

The authors acknowledge the Singosari National Artificial Insemination Center (SNAIC) Malang, East Java Indonesia for providing the valuable data.

\section{REFERENCES}

[1] Abdullah T \& Tantri F. Manajemen Pemasaran (1st ed.). Depok: PT. Rajagrafindo Persada. 2019.

[2] Almsalam S. The Effects of Customer Expectation and Perceived Service Quality on Customer Satisfaction. International Journal of Business and Management Invention. 3(8), 79-84. 2014.

[3] Andreas C. Pengaruh Kualitas Produk terhadap Loyalitas Pelanggan dengan Kepuasan sebagai Variabel Intervening. Jurnal Ilmu dan Riset Manajemen. 5(5). 2016.

[4] Arianty N. Pengaruh Kualitas Pelayanan dan Kualitas Produk terhadap Kepuasan Konsumen Handphone Samsung. Jurnal Ilmiah Manlajemen dan Bisnis. 16(02). 2015.

[5] Basir, M., Modding, B., Kamase, J., \& Hasan, S. Effect of Service Quality, Orientation Service and Pricing on Loyalty and Customer Satisfaction in Marine Transportation Services. International Journal of Humanities and Social Invention, 4(6), 01-06. 2015.

[6] Budhiasa S. Multivariate dengan Aplikasi SEM PLS SMARTPLS 3.2.6. Denpasar (ID): Udayana University Press. 2016.

[7] Dimyati, M., \& Subagio, N. A. Impact of Service Quality, Price and Brand on Loyalty with the Mediation of Customer Satisfaction on Pos Ekspres in East Jawa. Mediterranean Journal of Social Sciences, 7(4), 74 86. 2016.

[8] Hair JF, Black WC, Babin BJ, Anderson RE. Multivariate Data Analysis 7th Edition. New Jersey (US): Prentice Hall. 2009.

[9] Hartono M. \& Raharjo H. Exploring the Mediating Role of Affective and Cognitive Satisfaction on The Effect of Service Quality on Loyalty. Total Quality Management. 26(9), 971-985. 2015.

[10] Hayati YH. \& Sekartaji G. Pengaruh Kualitas Produk terhadap Kepuasan Konsumen di Restoran Bebek dan Ayam Goreng Pak Ndut Solo. Jurnal Ilmiah Manajemen Fakultas Ekonomi (JIMPE). 1(1), 49-56. 2016.

[11] Hermawan B. Pengaruh Kualitas Produk terhadap Kepuasan, Reputasi Merek dan Loyalitas Konsumen Jamu Tolak Angin PT. Sido Muncul. ManajemenTeori dan Terapan. 4(2). 2011. 
[12] Iriyanti E, Qomariah N, \& Suharto A. Pengaruh Harga, Kualitas Produk dan Lokasi Terhadap Loyalitas Pelanggan Melalui Kepuasan Sebagai Variabel Intervening pada Depot Mie Pangsit Jember. Jurnal Manajemen dan Bisnis Indonesia. 2(1), 1-15. 2016

[13] Ishaq MI, Bhutta HM, Hamayun AA, Danish RQ, \& Hussain NM. Role of Corporate Image, Product Quality and Customer Value in Customer Loyalty: Intervening Effect of Customer Satsfaction. Journal of Basic and Applied Scientific Research. 4, 89-97. 2014.

[14] Jahanshahi AA, Gashti NAH, Mirdamadi SA, Nawaser K, \& Khaksar SMS. Study the Effects of Customer Service and Product quality on Customer Satisfaction and Loyalty. International Journal of Humanities and Social Science. 1(7), 253-260. 2011.

[15] Kotler, P.\& Keller, KL. Manajemen Pemasaran (II). Jakarta: PT. Indeks. 2018.

[16] Kusumah EP. Customer Loyalty Model: Customer Satisfaction as Intervening Variable. Ecoforum. 7(2). 2018.

[17] Lupiyoadi R. ManajemenPemasaranJasa (3rd ed). Jakarta: SalembaEmpat. 2018.

[18] Mardalis A. Meraih Loyalitas Pelanggan. BENEFIT. 9(2): 111-119. 2005.

[19] Musanto T. Faktor-Faktor Kepuasan Pelanggan dan Loyalitas Pelanggan : Studi Kasus pada CV. Sarana Media Advertising Surabaya. Manajemen \& Kewirausahaan. 6(2), 123-136. 2014.

[20] Nurlina L. Upaya Transformasi Peternak Sapi Perah melalui Keseimbangan Dimensi Sosio-Kultural dan Teknis-Ekonomis. Scientific Article. Faculty of Animal Husbandry, Padjadjaran University. 2007.

[21] Paramitha-Wendha AAA, Rahyuda I, \&Suasana IGAK. Pengaruh Kualitas Layanan Terhadap Kepuasan dan Loyalitas Pelanggan Garuda Indonesia di Denpasar. Manajemen, Strategi Bisnis dan Kewirausahaan, 7(1). 2013.

[22] Priansa, D. J. Perilaku Konsumen Dalam Persaingan Bisnis Kontemporer. Bandung: Alfabeta. 2017.

[23] Priyo JS, Mohamad B, \&Adetunji RR. An Examination of the Effects of Service Quality and Customer Satisfaction on Customer Loyalty in the Hotel Industry. International Journal of Supply Chain Management. 8(1), 653-663. 2019.

[24] Putro SW, Semuel H, \& Brahmana MRRK. Pengaruh Kualitas Layanandankualitas Produkterhadap Kepuasan Pelanggan dan Loyalitas Konsumen Restoran Happy Garden Surabaya. Manajemen Pemasaran. 2(1), 1-9. 2014.

[25] Rashid, Abdul \& Rokade, Varsha. Service Quality Influence Customer Satisfaction and Loyalty. UKH Journal of Social Sciences 3(1):50-61. pp50-61. 2019.

[26] Sa'adah I, Mukson, \& Ondho YS. Pengukuran Tingkat Kepuasan Peternak Dalam Pelayanan Inseminasi Buatan Menggunakan Analisis Customer Satisfication Index (CSI) dan Importance Performance Analysis (IPA).Jurnal Ekonomi Pertanian dan Agribisnis (JEPA). 3(3), 557-567. 2019.

[27] Saputra MH. Membangun Loyalitas Pelanggan Melalui Penerapan Strategi Relationship Marketing. SEGMEN Jurnal Manjemendan Bisnis. No. 01. 2019.

[28] Schuh H. Comparison between liquid and deep-frozen semen for artificial insemination in developing and developed countries. FAO World Animal Review. No. 70-71, 1992/1-2.

[29] Sembiring IJ, Suharyono, \& Kusumawati A. Pengaruh Kualitas Produk dan Kualitas Pelayanan terhadap Kepuasan Pelanggan dalam Membentuk Loyalitas Pelanggan. Jurnal Administrasi Bisnis (JAB). 15(1). 2014.

[30] Singh I. \& Balhara AK. New approaches in buffalo artificial insemination programs with special reference to India. Theriogenology. 86(1), 194-199. 2016.

[31] Srivastava M.\& Rai AK. Investigating the Mediating Effect of Customer Satisfaction in the Service Quality-Customer Loyalty Relationship. 26, 95-109. 2013.

[32] Sugiyono. Metode Penelitian Kuantitatif (1st ed.). Bandung: CV. Alfabeta. 2018.

[33] Tjiptono F.\& Diana A. KepuasanPelangan-Konsep,PengukurandanStrategi (I). Yogyakarta: CV. Andi Offset. 2019.

[34] Toelihere MR. Fisiologi Reproduksi pada Ternak(II). Bandung: Angkasa. 1979.

[35] Xhema J, Metin H, \& Groumpos P. Switching-Cost, Corporate Image and Product Quality Effect on Customer Loyalty : Kosovo Retail Market. IFAC Papers Online. 287-292. 2018.

[36] Yuen, EFT. \& Chan, SSL. The Effect of Retail Service Quality and Product Quality on Customer Loyalty. Database Marketing \& Customer Strategy Management. 17(3/4), 222-240. 2010. 
AUTHORS' BIOGRAPHY

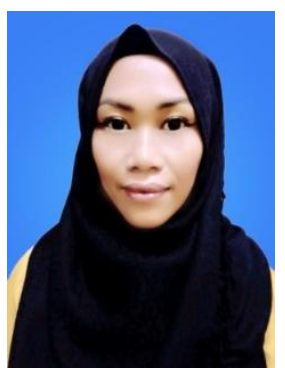

Dr. Rina Rahmawati, Lecturer of Management Science at STIE Malangkucecwara, East Java, Indonesia.

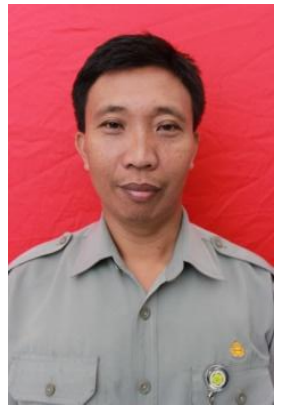

I Putu Eka Sentana, Head of Marketing and Cooperation Division at Singosari National Artificial Insemination Centre (SNAIC) Malang, under Directorate General of Livestock and Animal Health Services, Ministry of Agriculture Republic of Indonesia.

Citation: Rina Rahmawati, I P. Eka Sentana, "The Effect of Product Quality on Customer Loyalty with the Mediation of Customer Satisfaction" International Journal of Managerial Studies and Research (IJMSR), vol 9, no. 2, 2021, pp. 22-32. doi: https://doi.org/10.20431/2349-0349.0902004.

Copyright: (C) 2021 Authors. This is an open-access article distributed under the terms of the Creative Commons Attribution License, which permits unrestricted use, distribution, and reproduction in any medium, provided the original author and source are credited. 